enterprises]. Development of management and entrepreneur methods on transport, no. 28, pp. 28-36.

4. Primachev N.T., Primacheva N.N. (2011) Effektivnost' razvitiya morskoy transportnoy industrii [Efficiency of development of maritime transport industry]. Odessa: ONMA (in Russian).

5. Kraev V.I., Pantina T.A. (2003) Ekonomicheskaya otsenka investitsiy na vodnom transporte [Economic evaluation of investments in water transport industry]. Sankt-Petersburg: SPbGPU (in Russian).

6. Kulaev Yu.F. (2001) Metody otsenki investitsionnykh proektov na transporte [Methods of evaluation of investment projects in transport industry]. Kyiv: Transport of Ukraïne (in Russian).

7. Blank I.A. (2001) Investitsionnyy menedzhment [Investment management]. Kyiv: El'ga-N, Nika-Tsentr (in Russian).

8. Blank I.A. (2004) Upravlenie kapitalom [Capital management]. Kiev: El'ga-N, Nika-Tsentr (in Russian).
9. Bodi E., Keyn A., Markus A. (2008) Printsipy investitsiy [Principles of investments]. Moscow: Vil'yams (in Russian).

10. Bocharov V.V. (2000) Investitsionnyy menedzhment [Investment management]. Sankt-Petersburg: Piter (in Russian).

11. Granaturov V.M. (2002) Ekonomicheskiy risk. Sushchnost', metody izmereniya, puti snizheniya [Economic risk. Nature, methods of measuring, ways of minimization]. Moscow: DiS (in Russian).

12. Granaturov V.M., Litovchenko I.V. (2005) Upravlenie predprinimatel'skimi riskami: voprosy teorii $i$ praktiki [Entrepreneurial risks management: questions of theory and practice]. Odessa: Even (in Russian).

13. Donecj L.I. (2006) Ekonomichni ryzyky ta metody jikh vymirjuvannja [Economic risks and methods of its measuring]. Kyiv: Centr navchaljnoji literatury (in Ukraine).

УДК 330.322:656.2

\title{
РОЗРОБЛЕННЯ МОДЕЛІ УПРАВЛІННЯ ІНВЕСТИЦІЙНИМ ЗАБЕЗПЕЧЕННЯМ ПРОЄКТІВ РОЗВИТКУ ІНФРАСТРУКТУРИ ЗАЛІЗНИЧНОГО ТРАНСПОРТУ В УМОВАХ ТРАНСКОРДОННОЇ СПІВПРАЦІ
}

\author{
Корінь М.В., к.е.н., доцент, \\ Абдуллаєв А.І, махістр, \\ Польгуй Д.Г., махістр (УкрДУЗТ)
}

В статті вивчено існуючі підходи до систематизаиії та класифікації ризиків інфраструктурних проєктів. Виділено чотири групи (глобальні, транскордонні, начіональні, галузеві) потенційних ризиків проєктів розвитку інфраструктури залізничного транспорту, щзо реалізуються в рамках транскордонних регіонів. Розроблено модель управління інвестиційним забезпеченням інфраструктурних проєктів розвитку залізничного транспорту, яка трунтується на оцінюванні співвідношення

(C) Корінь М.В.,

Абдуллаєв А.І.,

Вісник економіки транспорту і промисловості № 67, 2019

Польгуй Д.Г. 
величини інфраструктурних ризиків та обсягу інфраструктурних інвестицій $i$ передбачає вибір альтернативних стратегій інвестування, щзо здійснюється 3 використання інструментарію інвестищійної підтримки $i$ мінімізації ризиків інфраструктурного проєкту.

Ключові слова: інфраструктурний ризик, модель управління, інфраструктурний проект, залізничний транспорт, інвестиційне забезпечення.

\title{
РАЗРАБОТКА МОДЕЛИ УПРАВЛЕНИЯ ИНВЕСТИЦИОННЫМ ОБЕСПЕЧЕНИЕМ ПРОЕКТОВ РАЗВИТИЯ ИНФРАСТРУКТУРЫ ЖЕЛЕЗНОДОРОЖНОГО ТРАНСПОРТА В УСЛОВИЯХ ТРАНСГРАНИЧНОГО СОТРУДНИЧЕСТВА
}

\author{
Коринь М.В., к.э.н, доцент, \\ Абдуллаев А.И., магистр, \\ Польгуй Д.Г., магистр (УкрГУЖТ)
}

\begin{abstract}
В статье изучены существующие подходы к систематизачии и классификации рисков инфраструктурных проектов. Вылделень четьре группь (глобальные, трансграничные, начиональные, отраслевые) потенциальных рисков проектов развития инфраструктуры железнодорожного транспорта, реализуемых в рамках трансграничных регионов. Разработана модель управления инвестиционным обеспечением инфраструктурных проектов развития железнодорожного транспорта, которая основывается на оценке соотношения величины инфраструктурных рисков и объема инфраструктурных инвестиций $u$ предусматривает выбор альтернативных стратегий инвестирования, осуществляется с использованием инструментария инвестищионной поддержки и минимизации рисков инфраструктурного проекту.

Ключевые слова: инфраструктурный риск, модель управления, инфраструктурный проект, жжелезнодорожнный транспорт, инвестиционное обеспечение.
\end{abstract}

\section{DEVELOPMENT OF A MODEL OF INVESTMENT SUPPORT MANAGEMENT FOR RAILWAY INFRASTRUCTURE DEVELOPMENT PROJECTS IN THE CONTEXT OF CROSS-BORDER COOPERATION}

\author{
Korin M., candidate of economic sciences, associate professor, \\ Abdullaiev A., master, \\ Poligoy D., master (USURT)
}

The article identifies that a key priority towards improving the quality of transport services railway transport defined by the implementation of major projects of the industry development related to quality improvement of railway infrastructure, rolling stock, electrification of plots and construction of transport-logistic services. For these projects the sector needs to attract huge investment because the existing state JSC "Ukrzaliznytsya" that is characterized by deterioration of the dynamics of workload, and accordingly lower profitability of transport allows you to self-Finance this kind of innovative-technological transformation. It is argued that the high level of risk of infrastructure projects, which is due to economic instability in the country and the presence of internal threats to the development of the industry, 
significantly reduce their attractiveness for potential partners and investors. It is determined that not only the decision on its financing, but also the amount of invested funds depends on the magnitude of the risks inherent in the infrastructure project. On this basis, the existing approaches to the systematization and classification of risks of infrastructure projects are studied. There are four groups (global, cross-border, national, sectoral) of potential risks of railway infrastructure development projects implemented within the framework of cross-border regions. The developed model of management of investment provision of infrastructure projects of railway transport development, which is based on assessing the value of infrastructure risks and the volume of infrastructure investments and involves the selection of alternative investment strategies is carried out with use of instruments of investment support and risk mitigation infrastructure project. It is proved that the introduction of this model will allow a thorough approach to the choice of alternative sources of investment support for the development of railway transport in the context of large-scale infrastructure projects and qualitatively improve the mechanisms for attracting investment for their implementation.

Keywords: infrastructure risk, management model, infrastructure project, railway transport, investment support.

Актуальність

Трансформаційні процеси, що наразі відбуваються в системі функціонування АТ «Укрзалізниця», орієнтовані не лише на реалізацію організаційних перетворень в галузі, а й на суттєве покращення якості транспортно-логістичного обслуговування, перетворення залізничного транспорту в компанію європейського рівня. Ключовим пріоритетом в напрямку покращення якості транспортних послуг залізничного транспорту визначено реалізацію масштабних проєктів розвитку галузі, пов'язаних з якісним покращенням стану інфраструктури залізниць, оновленням рухомого складу, електрифікацією ділянок та розбудовою об'єктів транспортнологістичного обслуговування.

Для реалізації цих проєктів галузь потребує залучення величезних інвестицій, адже існуюче становище АТ «Укрзалізниця», що характеризується погіршенням динаміки обсягових показників роботи, а відповідно зниженням дохідності перевезень, не дозволяє самостійно фінансувати такого роду інноваційно-технологічні перетворення. Однак високий рівень ризику інфраструктурних проєктів, що зумовлено економічною нестабільністю в країні та наявністю внутрішніх загроз розвитку галузі, значно знижує їх привабливість для потенційних партнерів і інвесторів. Адже саме від величини властивих інфраструктурному проєкту ризиків залежить не лише рішення про його фінансування, але й обсяг інвестованих коштів. Враховуючи те, що ризики мають визначальний вплив на можливість фінансування інфраструктурного проєкту розвитку залізничного транспорту, на сьогоднішній день для підвищення їх привабливості для інвесторів існує гостра потреба у розробленні ефективних механізмів інвестиційного забезпечення їх виконання.

Аналіз досліджень та публікацій. Питанню інвестиційного забезпечення процесів реалізації інфраструктурних проєктів розвитку залізничного транспорту приділяється значна увага вченими вітчизняної та закордонної наукових шкіл. Свої наукові розробки вирішенню даної проблеми присвятили такі науковцідослідники, як І.В. Воловельська, В. Л. Дикань, Г.Д. Ейтутіс, М.В. Корінь, О. Г. Кірдіна, О.І. Никифорук, Г.В. Обруч, В.О. Овчинникова, І.В. Токмакова та інші [1-8]. В цілому, високо оцінюючи вагомість наукових розробок даних вчених $\mathrm{y}$ вирішення проблеми підвищення рівня інвестиційної привабливості галузі та враховуючи стратегічну важливість інфраструктурних проєктів для 
покращення якості транспортного обслуговування на залізничному транспорті, наразі існує потреба у розробленні пропозицій щодо управління процесами інвестиційного забезпечення їх реалізації в умовах існування численних ризиків і загроз функціонування галузі та поглиблення процесів транскордонної співпраці.

Мета статті. Тому, метою статті $\epsilon$ дослідження потенційних ризиків інфраструктурного проєкту розвитку залізничного транспорту та розроблення моделі управління інвестиційним забезпечення їх реалізації в умовах поглиблення процесів транскордонної співпраці.

Виклад основного матеріалу. В цілому інфраструктурний ризик можна трактувати як ситуацію невизначеності, що в підсумку може призвести до невиконання проєкту. Інфраструктурні ризики мають різну природу виникнення, i їхня величина залежить від значної кількості факторів.

В науковій літературі існує значна кількість поглядів на природу та фактори виникнення ризиків, в тому числі й інфраструктурних. Більшість вчених розглядають ризики проєктів в процесів їхньої реалізації за механізмами державноприватного партнерства (ДПП). Так, Черевиков Є.Л. та Єрофеєєва Т.А., розглядаючи особливості управління ризиками проєктів державно-приватного партнерства, відповідно до етапів реалізації проєкту виділяють комерційні, ризики затримки проєктів, технологічні ризики, ризики придбання землі, ризики надмірних витрат, операційно-експлуатаційні ризики, нормативні, регуляторні, політичні, соціальні, валютні та фінансові ризики i ризики форс-мажорних обставин [9].

Інший підхід до розподілу ризиків проєктів ДПП запропонований Помогайбог Б.В., який наводить відповідну їх класифікацію за PEST-класифікацією. Зокрема цим вченим виділяються такі ознаки ризиків за PEST-класифікацією, як політичні ризики (підгрупи: інституційні, політико-правові, ризики порядку та безпеки в країні), економічні (підгрупи: ризики започаткування бізнесу, ризики невиконання зобов'язань, фінансові ризики, ризики попиту), соціальноекологічні (підгрупи: соціальні, екологічні), технічні (ризик затримки будівництва, ризик незавершеного будівництва) ризики [10].

Безпосередньо аналізу ризиків проєктів розвитку інфраструктури, хоча і в сфері рекреації, присвятив свою працю Славік Р.В., який розподілив ризики на такі групи: соціально-економічні ризики місцевої громади, екологічні ризик, ризики інвестора, які в свою чергу поділено на ризики макро-, мезо- та мікрорівня [11].

Сментина Н. В., Клєвцєвич Н. А. у своїй праці [12, с. 116-119] приділяють увагу вивченню видів ризиків інфраструктурних проєктів, а саме існуючим підходам до їхньої класифікації. Серед ключових різновидів ризиків цими науковцями пропонується розрізняти: ризик, пов'язані з дією зовнішніх обставин, політичні ризики, ризики невиконання сторонами партнерства взятих на себе зобов'язань, комерційні, фінансові та екологічні ризики. Позитивно оцінюючи такий підхід до систематизації ризиків, в цілому варто зазначити, що дана класифікація має узагальнюючий характер i не враховує особливостей інфраструктурних проєктів.

Серед тих підходів до систематизації та класифікації ризиків інфраструктурних проєктів, що зустрічаються у науковій літературі, найбільш адаптованим до вимог проєкту розвитку інфраструктури залізничного транспорту $\epsilon$ підхід, запропонований Малицькою К.О. Цей вчений, оцінюючи ефективність проєктного фінансування на залізничному транспорті, наводить матрицю ризиків 3 виділення прямих наслідків їхнього виникнення під час реалізації інфраструктурного проєкту на умовах концесії.

Серед ключових ризиків 
інфраструктурного проєкту Малицька К.О. виділяє: ризики під час здачі об'єкта в експлуатацію; ризики, пов'язані 3 необхідністю використання об'єкту; ризики проєктування; екологічні та фінансові ризики; форс-мажорні ризики; ризики, пов'язані 3 виробничими відносинами; ризики, пов'язані 3 прихованими дефектами; операційні та експлуатаційні ризики; ризики, пов'язані зі зміною законодавства; ризики, пов'язані $з$ залишковою вартістю основного капіталу; ризики морального зносу обладнання; ризики, пов'язані з модернізацією; ризики, пов'язані 3 технічним обслуговування об'єкта [13, с. 131-133].

Варто зазначити, що навіть попри те, що даний підхід адаптовано до особливостей інфраструктурного проєкту на залізничному транспорті, його застосування в умовах реалізації проєктів розвитку інфраструктури в межах транскордонних регіонів $\epsilon$ не цілком доцільним, оскільки не враховує особливості такого співробітництва залізниць.

Грунтуючись на наведених вище підходах до класифікації ризиків інфраструктурного проєкту, серед ризиків проєктів розвитку інфраструктури залізничного транспорту, що реалізуються в рамках транскордонних регіонів, доцільно виділити наступні групи: глобальні, транскордонні, національні, галузеві.

Так до глобальних ризиків інфраструктурного проєкту слід віднести: ризики настання глобальної фінансовоекономічної кризи; ризики погіршення взаємовідносин з країнами СС; ризик зміни глобальних транспортних пріоритетів; ризик виключення залізничного транспорту з карти TEN-T.

До ризиків транскордонного рівня, що можливі за умови співробітництва під реалізації інфраструктурних проєктів в транскордонних регіонах, належать: ризик погіршення правового поля транскордонного співробітництва через зміни в законодавстві; ризик погіршення ділового рейтингу стейкхолдерів транскордонного регіону; ризик відмови стейкхолдерів 3 транскордонних регіонів від участі у інфраструктурному проєкті; ризик порушення зобов'язань стейкхолдерами транскордонних регіонів та ін.

На національному рівні основні ризики інфраструктурного проєкту залізничного транспорту будуть пов'язані 3 економічною ситуацією в країні, а саме: ризик загострення політико-економічної кризи; ризик загострення воєнного конфлікту на Сході України; ризик знецінення національної валюти; ризик зміни законодавства в сфері залізничного транспорту; ризик недієвості уряду у сфері підтримки проєктів залізничного транспорту; ризик падіння попиту на послуги залізничного транспорту; ризик подальшої технологічної деградації виробництв; ризик ліквідації об'єктів науково-виробничої інфраструктури тощо.

Ризик галузевого рівня доцільно розподілити на такі групи:

- управлінські, що включатимуть такі ризики, як неузгодженості управлінських рішень i дій; корумпованості керівного складу; неефективності зв'язків між вертикалями управління та учасниками інфраструктурного проєкту; недбалості та зловживання обов'язками управлінського складу проєкту;

- виробничо-технологічні

охоплює вплив таких ризиків, як ризик низької якості виконання робіт за проєктом; ризик виходу з ладу обладнання; ризик низьких темпів оновлення виробничих баз та рівня впровадження інноваційних технологій; ризик невідповідності інноваційних розробок потребам інфраструктурного проєкту; ризик низької якості залучених технологій $\mathrm{i}$ обладнання для інфраструктурного проєкту; ризик порушення виробництва; ризик недотримання термінів реалізації проєкту; ризик недотримання термінів 
постачань тощо;

- інформаційні ризики: ризик витоку комерційної інформації за проєктом; ризик порушення інформаційних зв'язків зі стейкхолдерами інфраструктурного проєкту тощо;

- фінансово-інвестицій

ризики:

ризик погіршення фінансово-економічного становища галузі; ризик реалізації тіньових схем використання інвестицій проєкту; ризик невиконання кредитних зобов'язань; ризик затримки інвестицій; ризик зростання відсотків за кредитами тощо;

- кадрові ризики включатимуть

такі ризики, як професійної некомпетентності, дефіциту персоналу; плинності кадрів; зниження продуктивності праці; зростання виробничого травматизму; супротиву та невиконання зобов'язань тощо.

Враховуючи визначені вище

потенційні ризики інфраструктурного проєкту, доцільно розкрити модель управління інвестиційним забезпеченням інфраструктурних проєктів розвитку залізничного транспорту, яка передбачає вибір альтернативних стратегій інвестування на розрахунок коефіцієнту інтегрованої ефективності інфраструктурних інвестицій, що розкриває співвідношення величини інфраструктурних ризиків та обсягу інфраструктурних інвестицій (рис. 1):

$$
K_{I I}^{\text {iнт.ефек. }}=\frac{T_{I P}}{T_{I I}}
$$

де $T_{I P}$ - темп зростання величини інфраструктурних ризиків за проєктом, \%;

$T_{\text {II }}$ - темп зростання обсягу інфраструктурних інвестицій за проєктом, $\%$.

Так, у випадку, якщо значення коефіцієнту інтегрованої ефективності інфраструктурних інвестицій $\left(K_{I I}^{\text {iнm.ефек. })}\right.$ менше 1, рівень інфраструктурних ризиків притаманних проєкту високий, інвестування є недоцільним, необхідно всі зусилля сконцентрувати на нейтралізації впливу інфраструктурних ризиків.

Якщо
інтегрованої інфраструктурних інвестицій $\left(K_{I I}^{\text {iнm.ефек. }}\right)$ дорівнює 1, рівень інфраструктурних ризиків, характерних для проєктів розвитку інфраструктури залізничного транспорту $\epsilon$ допустимим, інвестування в інфраструктурні проєкти $\epsilon$ можливим, однак необхідними $\epsilon$ заходи щодо попередження та мінімізації дії наявних ризиків.

За умови якщо значення коефіцієнту інтегрованої ефективності інфраструктурних інвестицій $\left(K_{I I}^{\text {iнm.ефек. }}\right)$ більше 1, інвестиції в інфраструктурні проєкти є низько ризиковими, доцільно реалізувати проєкти, здійснюючи постійний контроль і моніторинг рівня ризиків і загроз з метою їх попередження.

Варто відзначити, що нейтралізації впливу i попередження виникнення інфраструктурних ризиків під час реалізації проєкту розвитку інфраструктури залізничного транспорту в рамках транскордонного співробітництва доцільно застосувати як інструменти мінімізації ризиків, так i інструменти інвестиційної підтримки інфраструктурних проєктів. Серед ключових інструментів мінімізації інфраструктурних ризиків під час реалізації інфраструктурних проєктів на залізничному транспорті варто виділити такі, як страхування, лімітування, хеджування, сек'юритизація ризиків, картографування, диверсифікація, локалізація ризиків тощо.

До інструментів інвестиційної підтримки інфраструктурних проєктів залізничного транспорту, що реалізують в рамках транскордонних регіонів, варто віднести наступні [5; 14]: 
1. Ідентифікація ключових факторів впливу на процеси інвестування проєктів розвитку інфраструктури залізничного транспорту у транскордонному регіоні

$$
\checkmark L
$$

2. Встановлення взаємозв'язку між обсягом інвестицій в інфраструктурні проєкти розвитку залізничного транспорту та величиною інфраструктурних ризиків, пов'язаних з їхньою реалізацією у

транскордонному регіоні

3. Розроблення моделі планування інвестицій у проєкти розвитку інфраструктури залізничного транспорту та оцінювання впливу виявлених факторів на обсяг інфраструктурних інвестицій

$$
\checkmark 2
$$

4. Встановлення інфраструктурних ризиків і їх взаємозв'язку з обсягом інфраструктурних інвестицій на основі визначення коефіцієнта інтегрованої ефективності інфраструктурних інвестицій, що відображує співвідношення темпів зростання інфраструктурних ризиків за проєктами та обсягів інфраструктурних інвестицій $\left(K_{I I}^{\text {iнm.ефек . })}\right.$

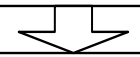

5. Прийняття рішень щодо інвестування інфраструктурних проєктів розвитку залізничного транспорту на основі отриманих значень коефіцієнта інтегрованої ефективності інфраструктурних інвестицій:

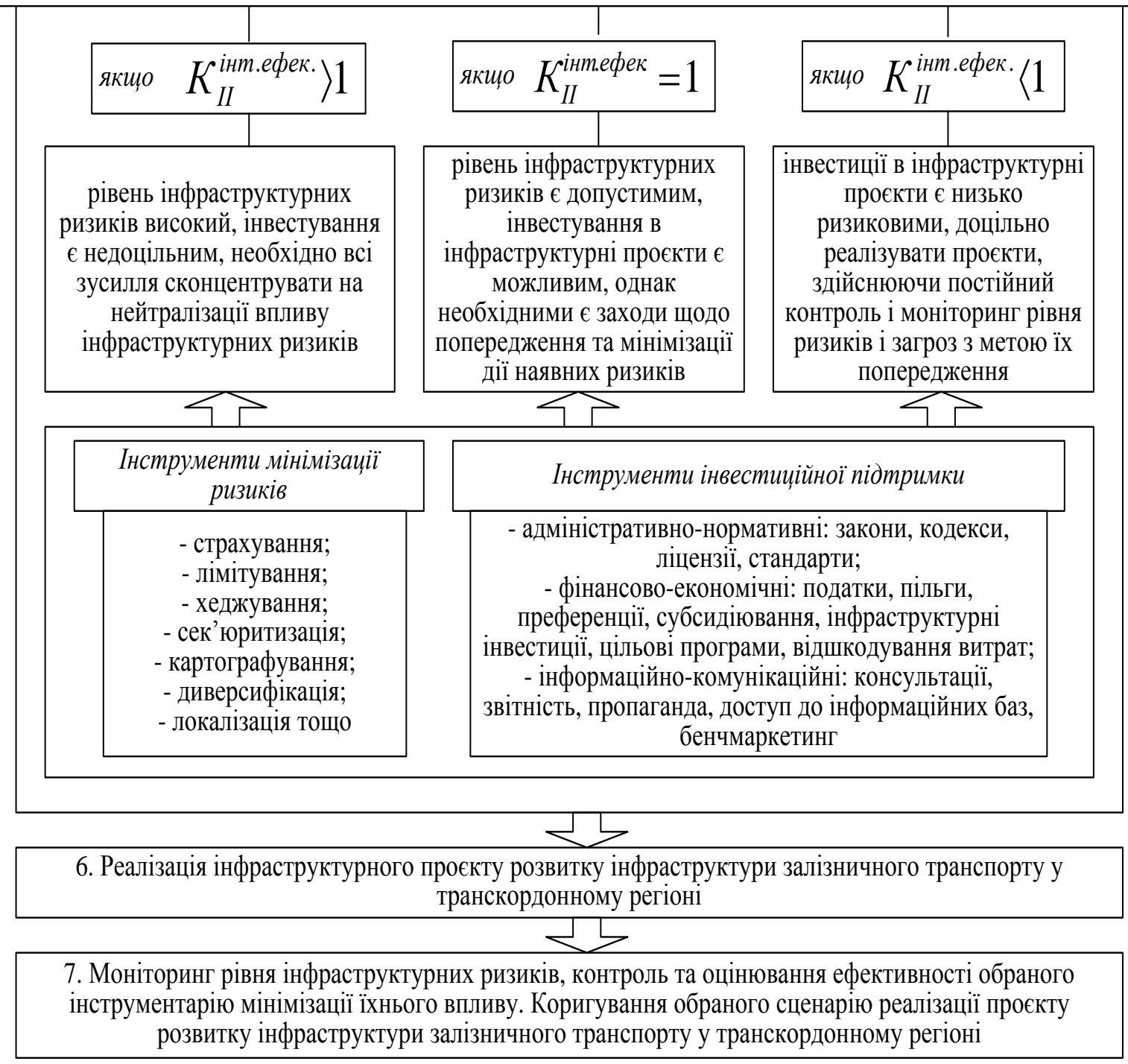

Рис. 1. Модель управління інвестиційним забезпеченням інфраструктурних проєктів розвитку залізничного транспорту в умовах транскордонної співпраці (розробка автора)

Вісник економіки транспорту і промисловості № 67, 2019 
- адміністративно-нормативні передбачають покращення правового поля реалізації інвестиційної діяльності, транскордонного співробітництва та в цілому діяльності залізничного транспорту і полягають в удосконаленні законів, кодексів, а також розробленні ліцензій, стандартів;

фінансово-економічні інструменти підтримки пов'язані 3 проведення сприятливої державної політики підтримки інфраструктурних проєктів та передбачають спрощення системи податків, надання пільг, преференцій,

субсидіювання

безпосередньо проєктів, надання інфраструктурних інвестицій, реалізацію цільових програм та відшкодування витрат за проєктами; інформаційно-комунікаційні інструменти включають консультації, звітність, пропаганду, доступ до інформаційних баз, бенчмаркетинг тощо.

Варто зазначити, що до інструментів інвестиційної підтримки інфраструктурних проєктів розвитку залізничного транспорту можна віднести і бюджетне фінансування; державні дотації та субвенції; пільгове оподаткування; концесію; лізинг; кредити; гранти; корпоративні, інфраструктурні та єврооблігації; реструктуризацію боргових запозичень; акціонування капіталу; прямі інвестиції; спільне будівництво та виробництво;

партнерство; державно-приватне співфінансування інвестиційних проєктів. Також можливе застосування інструментів компенсації отриманих інвестиційних коштів, що включають такі з них, як пільгові платежі; виплату суми кредиту i кредитних відсотків; погашення боргу за облігаціями та виплату відсотків; виплату дивідендів за акціями; виплату прибутку на інвестований капітал; здійснення лізингових платежів; виплату прибутку від реалізації спільних інвестиційних проєктів тощо. Звичайно, цей перелік не $\epsilon$ вичерпним i може включати інші інструменти інвестиційної підтримки як на національному, так і міжнародному рівні $[5 ; 14]$.

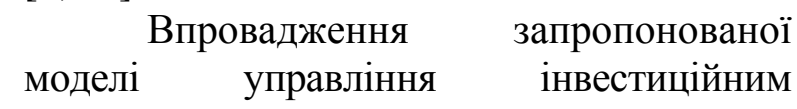
забезпеченням інфраструктурних проєктів розвитку залізничного транспорту в умовах транскордонної співпраці дозволить грунтовно підійти до вибору альтернативних джерел інвестиційного забезпечення розвитку залізничного транспорту в контексті реалізації масштабних інфраструктурних проєктів i якісно покращити механізми залучення інвестицій для їх реалізації.

Висновок. Таким чином, сьогодні для реалізації проєктів розвитку інфраструктури залізничний транспорт потребує залучення масштабних інвестицій. Обсяг та рішення щодо інвестування у процеси інноваційнотехнологічного перетворення інфраструктури галузі залежить від величини притаманних інфраструктурному проєкту інфраструктурних ризиків. Грунтуючись на цьому, в статті проаналізовано підходи до систематизації інфраструктурних ризиків та на цій основі виділено чотири групи потенційних ризиків проєктів розвитку інфраструктури залізничного транспорту, що реалізуються в рамках транскордонних регіонів. Розроблено модель управління інвестиційним забезпеченням інфраструктурних проєктів розвитку залізничного транспорту, яка грунтується на оцінюванні співвідношення величини інфраструктурних ризиків та обсягу інфраструктурних інвестицій i передбачає вибір альтернативних стратегій інвестування, що здійснюється 3 використання інструментарію інвестиційної підтримки i мінімізації ризиків інфраструктурного проєкту.

\section{ПЕРЕЛІК ВИКОРИСТАНИХ ДЖЕРЕЛ}

1. Дикань

В.Л.

Концептуальные подходы к обеспечению 
экономической безопасности предприятия / В.Л. Дикань, И.В. Воловельская // Вісник економіки транспорту і промисловості. 2018. - № 64. - C. 11-18.

2. Дикань В. Л. Інжинірингомаркетинговий центр інноваційних технологій як основа активізації інноваційно-інвестиційного потенціалу підприємств залізничного транспорту / В. Л. Дикань, I. В. Соломніков // Вісник економіки транспорту та промисловості. 2017. - Вип. 57. - С. 9-20.

3. Ейтутіс Г. Потенційні джерела інвестування в розвиток залізничного транспорту України: можливості їх диверсифікації / Г. Ейтутіс, О. Никифорук, О. Бойко // Економіст. -2012. - № 8. - С. 6469.

4. Кірдіна О. Г. Інтеграційні процеси та задачі інвестиційноінноваційного розвитку залізничного комплексу / О. Г. Кірдіна // Вісник ХНАУ - 2010. - № 11. - C. 189-201.

5. Корінь М. В. Інвестиційне забезпечення розвитку залізничного транспорту України / М. В. Корінь, М. В. Кондратюк, Г. В. Обруч // Вісник економіки транспорту і промисловості. 2018. - № 62. - С. 249 - 259.

6. Никифорук Е. И. Перспективы финансирования транспортных проектов в рамках международной финансовой помощи / Е. И. Никифорук, Л. Ю.Чмырева, Н. А. Федяй // Экономика Украины. - 2015. № 4 (633). - С. 45-57.

7. Овчиннікова В.О. Стратегічне управління розвитком залізничного транспорту України: монографія / В.О. Овчиннікова. - Харків: УкрДУзТ, 2017. $426 \mathrm{c}$.

8. Токмакова I. В. Теоретикометодологічні основи забезпечення гармонійного розвитку залізничного транспорту України: дис. на здобуття наук. ступеня докт. екон. наук; спеціальність: 08.00.03 / Укр. держ. ун-тет залізничного транспорту / І. В. Токмакова. - Харків, 2015. -456 c.

9. Черевиков Є. Л. Управління ризиками проектів державно-приватного партнерства / С. Л. Черевиков, Т. А.Єрофеєєва // Наукові праці НДФІ. - 2010. - 4 (53). - C. 48-53.

10. Помогайбог Б. В. Вертикальний аналіз ризиків ДПП-проектів у розрізі факторів їх формування / Б. В. Помогайбог // Інвестиції: практика та досвід. - 2017. № 16. - C. 120-125.

11. Славік Р. В. Методологічні аспекти дослідження ризиків інфраструктурної розбудови рекреаційних територій / Р. В. Славік // Вісник Дніпропетровського університету. Серія «Економіка». - 2012. - 63. - С. 220-228.

12. Сментина Н. В., Клєвцєвич Н. А. Управління інфраструктурними проектами: навчальний посібник / Н. В. Сментина, Н. А. Клєвцєвич. - Одеса: OHEУ, 2016. - 193 c.

13. Малицкая Е.А. Оценка эффективносты проектного финансирования на железнодорожном транспорте (методологический подход): дис. на соиск. учен. степени канд. экон. наук; спецыальноть: 08.00.10 / Институт экономики Российской академии наук. 2014. 215 c.

14. Корінь М. В. Розвиток інфраструктури залізничного транспорту в умовах транскордонного співробітництва: монографія / М.В. Корінь. - Харків: УкрДУЗТ, 2019. - 401 с.

\section{REFERENCES}

1. Dykan' V.L., Volovel'skaya I.V. (2018) Kontseptual'nye podkhody k obespechenyyu ékonomycheskoy bezopasnosty predpryyatyya [Conceptual approaches to ensuring the economic security of the enterprise] // The bulletin of Transport and Industry Economics. № 64. pp. 11-18. (in Russian)

2. Dykan' V. L., Solomnikov I. V. (2017) Inzhynirynho-marketynhovyy tsentr innovatsiynykh tekhnolohiy yak osnova aktyvizatsiyi innovatsiyno-investytsiynoho potentsialu pidpryyemstv zaliznychnoho 
transportu [Engineering and Marketing Center for Innovative Technologies as a Basis for Activating the Innovation and Investment Potential of Railway Transport Enterprises]. The bulletin of Transport and Industry Economics. № 57. pp. 9-20. (in Ukrainian)

3. Eytutis H., Nykyforuk O., Boyko O. (2012) Potentsiyni dzherela investuvannya $\mathrm{V}$ rozvytok zaliznychnoho transportu Ukrayiny: mozhlyvosti yikh dyversyfikatsiyi [Potential sources of investment in the development of rail transport in Ukraine: opportunities for their diversification]. Ekonomist. № 8. pp. 64-69.

4. Kirdina O. H. (2011) Intehratsiyni protsesy ta zadachi investytsiynoinnovatsiynoho rozvytku zaliznychnoho kompleksu [Integration processes and problems of investment and innovation development of the railway complex]. The bulletin of Transport and Industry Economics. №11. pp. 189-201. (in Ukrainian)

5. Korin' M. V., Kondratyuk M. V., Obruch H. V. Investytsiyne zabezpechennya rozvytku zaliznychnoho transportu Ukrayiny [Investment support for the development of railway transport in Ukraine]. The bulletin of Transport and Industry Economics. № 62. pp. 249 - 259. (in Ukrainian)

6. Nykyforuk E. Y., Chmyreva L. YU., Fedyay N. A. (2015) Perspektyvy fynansyrovanyya transportnykh proyektov $\mathrm{v}$ ramkakh mezhdunarodnoy fynansovoy pomoshchy [Prospects of financing transport projects in the framework of international financial assistance]. Ékonomyka Ukrayny. № 4 (633). pp. 45-57. (in Ukrainian)

7. Ovchynnikova V.O. (2017) Stratehichne upravlinnya rozvytkom zaliznychnoho transportu Ukrayiny [Strategic Management of Railway Transport Development in Ukraine]: monohrafiya. Kharkiv: UkrDUZT. (in Ukrainian)

8. Tokmakova I. V. (2015) Teoretykometodolohichni osnovy zabezpechennya harmoniynoho rozvytku zaliznychnoho transportu Ukrayiny [Theoretical and methodological foundations of ensuring the harmonious development of railway transport in Ukraine]: dys. na zdobuttya nauk. stupenya dokt. ekon. nauk; spetsial'nist': 08.00.03 / Ukr. state. Univ. of the Railway Transport. Kharkiv. (in Ukrainian)

9. Cherevykov YE. L., Yerofeyeyeva T. A. (2010) Upravlinnya ryzykamy proektiv derzhavno-pryvatnoho partnerstva [Risk Management of Public-Private Partnership Projects]. Naukovi pratsi NDFI. №4 (53). pp. 48-53. (in Ukrainian)

10. Pomohayboh B. V. (2017) Vertykal'nyy analiz ryzykiv DPP-proektiv u rozrizi faktoriv yikh formuvannya [Vertical risk analysis of PPP projects in the context of their formation factors]. Investytsiyi: praktyka ta dosvid. № 16. pp. 120-125. (in Ukrainian)

11. Slavik R. V. (2012) Metodolohichni aspekty doslidzhennya ryzykiv infrastrukturnoyi rozbudovy rekreatsiynykh terytoriy [Methodological aspects of research of risks of infrastructural development of recreational territories]. Visnyk Dnipropetrovs'koho universytetu. Seriya «Ekonomika». № 63. pp. 220-228. (in Ukrainian)

12. Smentyna N. V., Klyevtsyevych N. A. (2016) Upravlinnya infrastrukturnymy proektamy [Infrastructure project management]: navchal'nyy posibnyk. Odesa: ONEU. (in Ukrainian)

13. Malytskaya E.A. (2014) Otsenka éffektyvnosty proektnoho fynansyrovanyya na zheleznodorozhnom transportu (metodolohycheskyy podkhod) [Assessment of the effectiveness of project financing on railway transport (methodological approach)]: dys. na soysk. uchen. stepeny kand. ékon. nauk; spetsyal'not': 08.00.10 / Ynstytut ékonomyky Rossyyskoy akademyy nauk. 2014. (in Russian)

14. Korin' M. V. (2019) Rozvytok infrastruktury zaliznychnoho transportu $v$ umovakh transkordonnoho spivrobitnytstva [Development of railway transport infrastructure in conditions of cross-border cooperation]: monohrafiya. Kharkiv: UkrDUZT. (in Ukrainian) 